\title{
Regulation of net hepatic glucose uptake: interaction of neural and pancreatic mechanisms
}

\author{
MC Moore, AD Cherrington \\ Department of Molecular Physiology and Biophysics, Vanderbilt University School of Medicine, \\ Nashville, TN 37232-0615, USA
}

(Received 29 November 1995; accepted 28 May 1996)

\begin{abstract}
Summary - Insulin and glucagon levels, the mass of glucose presented to the liver and the portal signal are important regulators of the liver's response to glucose delivery. The portal signal not only serves to direct glucose into the liver but also appears to stimulate its deposition in glycogen. Moreover, the portal signal impacts on tissues other than the liver: intraportal glucose delivery is associated with changes in glucose uptake by nonhepatic tissues and neurally-mediated enhancement of pancreatic insulin secretion. Our current understanding of the neural control of hepatic glucose metabolism includes a tonic block to the entry of glucose into the liver, probably mediated both by sympathetic neural activity and by a low insulin:glucagon ratio. An increase in the portal vein glucose level is detected by sensors in the portal region, which cause a decrease in the firing rate in the afferent fibers in the hepatic branch of the vagus nerve. The change in the afferent firing rate is processed in the hypothalamus and instigates a change in the efferent firing rate in the hepatic and pancreatic branches of the vagus (with corresponding increases in insulin secretion and net hepatic glucose uptake). The portal signal thus relieves the sympathetic inhibition of hepatic glucose uptake and enhances hepatic glucose uptake directly by stimulating the parasympathetic innervation to the liver and indirectly by enhancing insulin release.
\end{abstract}

liver / glucose / nervous system / insulin

Résumé - Interaction entre facteurs nerveux et pancréatiques conduisant à l'utilisation nette de glucose par le foie. Les niveaux de concentration en insuline et en glucagon, la quantité de glucose arrivant au foie, et le signal porte sont d'importants paramètres modulant la réponse hépatique à la fourniture de glucose. Le signal porte favorise non seulement la captation nette de glucose par le foie, mais également son stockage sous forme de glycogène. De plus, le signal porte affecte d'autres tissus que le foie : à la fourniture intraportable de glucose, sont associés des changements de l'utilisation de glucose par des tissus extra-hépatiques, ainsi qu'une augmentation de la sécrétion dinsuline contrôlée par le système nerveux. Dans l'état actuel de nos connaissances, le captage de glucose par le foie semble freiné par un stimulus nerveux d'origine sympathique et un faible rapport insuline-glucagon. L'augmentation de la glycémie portale est détectée par des capteurs situés dans la région portale qui vont provoquer une dimunution de l'activation des fibres afférentes de la branche hépatique du nerf vague. Ce changement d'activation des fibres nerveuses afférentes, relayé au niveau hypo- 
thalamique, induit un changement d'activation des fibres efférentes des branches hépatique et pancréatique du nerf vague (associé aux stimulations correspondantes de la sécrétion d'insuline et de l'utilisation nette de glucose par le foie). En définitive, le signal porte module l'utilisation hépatique de glucose, d'une part en levant son inhibition par la voie nerveuse sympathique, d'autre part en la stimulant, directement, par la voie nerveuse parasympathique du foie et, indirectement, par l'augmentation de la sécrétion d'insuline.

foie / glucose / système nerveux / insuline

The liver plays a key role in maintaining glucose homeostatis, since it is the primary organ with the ability to function as both a producer and a consumer of glucose. This bifunctional role requires that a signal or signals exist to indicate to the liver the need to make the transition between net output during fasting and net uptake of glucose in response to feeding. We will discuss the combination of signals, including changes in circulating substrate concentrations, hormonal secretion and neural activity, which have been found to contribute to the regulation of net hepatic glucose uptake (NHGU) in the fed state.

\section{REGULATION OF NET HEPATIC GLUCOSE UPTAKE}

\section{Response to enteral feeding of glucose}

Following enteral (oral, intragastric or intraduodenal) glucose delivery, rates of NHGU in the conscious dog or pig have been reported to reach 16.7 to 41.6 $\mu \mathrm{mol} . \mathrm{kg}^{-1} \cdot \mathrm{min}^{-1}$ (Abumrad et al, 1982; Bergman et al, 1982; Ishida et al, 1983; Barrett et al, 1985; Radziuk, 1987; Moore et al, 1991). These rates of NHGU were achieved with the pancreatic hormones free to change; arterial plasma glucose concentrations were 7.8 to $10.3 \mathrm{mmol} / \mathrm{L}(\sim 1.5$ - to two-fold basal), and arterial plasma insulin concentrations ranged from 300 to 558 $\mathrm{pmol} / \mathrm{L}(\sim$ five- to ten-fold basal) (Abumrad et al, 1982; Bergman et al, 1982; Ishida et al, 1983; Barrett et al, 1985; Radziuk, 1987; Moore et al, 1991). It is difficult to assess NHGU in humans because of the ethical constraints imposed by the necessity of cannulating the portal vein. However, net splanchnic glucose uptake (NSGU; net glucose uptake by the liver and gastrointestinal tract) in humans was $32.8 \mu \mathrm{mol} . \mathrm{kg}^{-1} . \mathrm{min}^{-1}$ following oral ingestion of $1.2 \mathrm{~g}$ glucose $/ \mathrm{kg}$ body weight; plasma glucose and insulin concentrations were $12.4 \mathrm{mmol} / \mathrm{L}$ and $918 \mathrm{pmol} / \mathrm{L}$, respectively (DeFronzo et al, 1978). Thus, under conditions where physiologic levels of hyperglycemia and hyperinsulinemia are achieved, enteral glucose delivery is able to produce a substantial amount of NHGU or NSGU.

\section{Effect of glucose}

Studies in both humans and dogs have shown that, in the absence of a rise in insulin hyperglycemia in the physiologic range ( $<12.5 \mathrm{mmol} / \mathrm{L}$ ) does not result in NSGU or NHGU. In humans, increasing the plasma glucose level from 5.5 to $12.4 \mathrm{mmol} / \mathrm{L}$ (by intravenous glucose infusion) under insulinopenic conditions caused hepatic glucose production to decrease $74 \%$, but splanchnic glucose uptake did not increase significantly over that observed during conditions of euglycemia and basal insulinemia (DeFronzo and Ferrannini, 1987). Similarly, doubling the glucose level by peripheral vein glucose infusion, in the presence of basal 
levels of insulin and glucagon, decreased net hepatic glucose output $\sim 60 \%$ in the conscious dog but did not result in NHGU (McGuinness et al, 1989). Thus, hyperglycemia greater than that normally observed in the postprandial state suppressed hepatic glucose output but was unable, by itself, to induce the liver to become a net consumer of glucose.

\section{Actions of insulin and glucagon}

Insulin has long been recognized as a regulator of hepatic glucose uptake. Nevertheless, physiologic hyperinsulinemia, in the absence of a rise in circulating glucose concentrations, does not stimulate significant rates of NHGU. In humans, moderate hyperinsulinemia (plasma concentration $318 \mathrm{pmol} / \mathrm{L}$ ) reduced net splanchic glucose output from 9.4 to $0.2 \mu \mathrm{mol} . \mathrm{kg}^{-1} \cdot \mathrm{min}^{-1}$ (DeFronzo and Ferrannini, 1987). More pronounced hyperinsulinemia $(\sim 600 \mathrm{pmol} / \mathrm{L})$ in the presence of euglycemia resulted in a low rate of NSGU, but even insulin concentrations $>6600 \mathrm{pmol} / \mathrm{L}$ produced a maximal NSGU of only $3.89 \mu \mathrm{mol} . \mathrm{kg}^{-1} \cdot \mathrm{min}^{-1}$ (DeFronzo and Ferrannini, 1987). Similar findings are apparent in the dog. Physiologic hyperinsulinemia $(720 \mathrm{pmol} / \mathrm{L})$ in the presence of euglycemia was accompagnied by NHGU of only $3.31 \mu \mathrm{mol} \cdot \mathrm{kg}^{-1} \cdot \mathrm{min}^{-1}$ (McGuinness et al, 1989). Pharmacologic hyperinsulinemia (12 $264 \mathrm{pmol} / \mathrm{L}$ ) resulted in substantial NHGU (16 $\left.\mu \mathrm{mol} . \mathrm{kg}^{-1} \cdot \mathrm{min}^{-1}\right)$ (McGuinness et al, 1989), although even those rates of NHGU were less than the maximal rates produced in response to enteral glucose feeding.

Plasma glucagon levels tend to decline following enteral glucose feeding. A selective decrease in glucagon levels in the presence of basal levels of insulin and glucose decreased hepatic glucose production but did not result in NHGU in dogs or NSGU in humans (Liljenquist et al, 1977; Shulman et al, 1978).

\section{Combined effect of postfeeding changes in glucose and pancreatic hormones}

The combination of hyperinsulinemia and hyperglycemia (resulting from a peripheral glucose infusion) is sufficient to produce $\mathrm{NHGU}$, but under physiologic conditions the rate of NHGU remains markedly reduced in comparison to the maximal rates produced by enteral glucose delivery. In humans, hyperinsulinemia (circulating insulin levels of 240 to $330 \mathrm{pmol} / \mathrm{L}$ ) coupled with hyperglycemia of peripheral origin (9.7 to 12.5 $\mathrm{mmol} / \mathrm{L}$ ) was associated with rates of NSGU of 5.6 to $8.9 \mu \mathrm{mol} . \mathrm{kg}^{-1} \cdot \mathrm{min}^{-1}$ (Sacca et al, 1982; DeFronzo and Ferrannini, 1987). Intestinal glucose uptake would have accounted for approximately half this amount, so there was little net uptake of glucose by the liver.

Peripheral glucose infusion producing arterial plasma glucose levels of 9 to $16 \mathrm{mmol} / \mathrm{L}$, combined with insulin levels of 210 to $2300 \mathrm{pmol} / \mathrm{L}$, resulted in rates of NHGU ranging from 5.6 to 27.8 $\mu \mathrm{mol} . \mathrm{kg}^{-1} \cdot \mathrm{min}^{-1}$ (Ishida et al, 1983; Barrett et al, 1985; Adkins-Marshall et al, 1990; Myers et al, 1991a, b). The rates of NHGU at the upper end of the range in these studies were similar to those rates observed following enteral glucose delivery, but the higher rates were achieved only with unphysiologic levels of glucose and/or insulin.

A fall in glucagon levels in the presence of basal insulinemia and hyperglycemia produced by peripheral glucose infusion has been shown to have much the same effect as hyperglycemia combined with hyperglycemia in both dogs and humans (Shulman et al, 1978; Liljenquist et al, 1979). 


\section{Effect of route of glucose delivery}

The fact that physiologic levels of hyperinsulinemia and hyperglycemia were insufficient to produce rates of NHGU comparable to those achieved with enteral glucose delivery prompted several laboratories to examine the effect of route of glucose delivery on NHGU. Initially it was proposed that glucose ingestion stimulated the release of a gut factor which enhanced NHGU (DeFronzo et al, 1978). However, several laboratories (Bergman et al, 1982; Ishida et al, 1983; Barrett et al, 1985) demonstrated independently in the conscious dog that NHGU was no different when glucose was administered enterally or infused directly into the portal vein so as to mimic the absorption profile of the enterally-delivered glucose. Although insulin levels and the load of glucose reaching the liver could not be precisely controlled in these studies (Bergman et al, 1982; Ishida et al, 1983; Barrett et al, 1985), they demonstrated that there was no need to invoke a putative gut factor to explain the enhancement of NHGU with enteral glucose delivery.
Subsequently, investigators in our laboratory (Adkins et al, 1987) doubled the glucose load reaching the liver with either peripheral or intraportal glucose infusion in dogs with fixed, basal levels of insulin and glucagon; NHGU did not occur during peripheral glucose infusion, but NHGU during intraportal infusion averaged 7.8 $\mu \mathrm{mol} . \mathrm{kg}^{-1} \cdot \mathrm{min}^{-1}$. During intraportal glucose delivery, the arterial glucose concentration was less than the portal vein concentration (a 'negative arterial-portal [A-P] gradient'), and conversely, during peripheral glucose infusion, the A-P gradient was positive. Adkins et al (1987) postulated that the negative $A-P$ gradient served as a signal (termed the 'portal signal'), probably neurally-mediated, which enhanced NHGU. Subsequent work from our laboratory defined the precise relationship between insulin, glycemic level (expressed as hepatic glucose load, or the mass of glucose reaching the liver) and the route of delivery in determining the magnitude of NHGU (table I). At any given insulin concentration and hepatic glucose load, within the physiologic range, intraportal infusion of glucose

Table I. Net hepatic glucose uptake (NHGU) in the conscious dog in the presence of basal glucagonemia, varying degrees of physiologic insulinemia and varying levels of hyperglycemia (expressed as hepatic glucose load ${ }^{*}$ ) produced by peripheral or portal glucose infusion in conscious dogs.

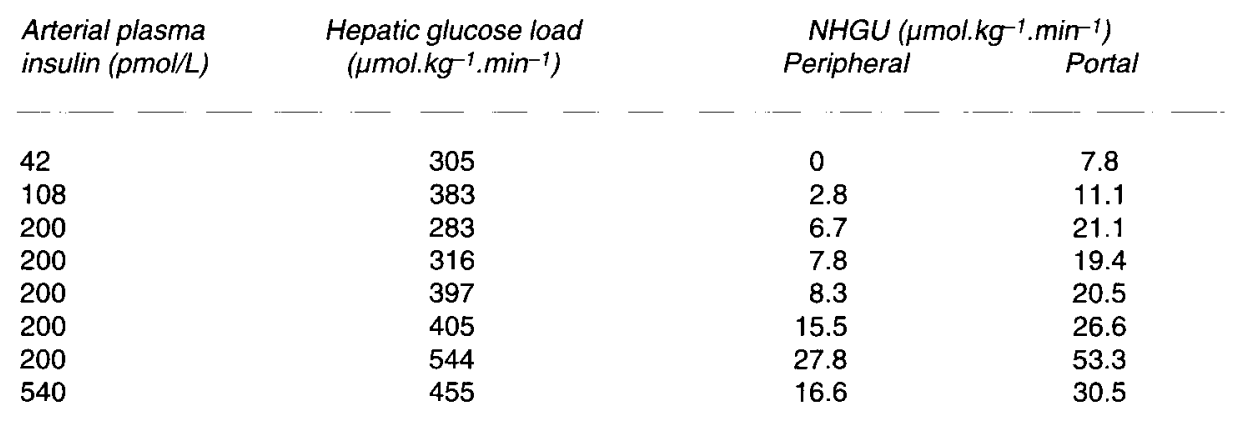

\footnotetext{
* Hepatic glucose load is calculated as the blood glucose concentrations in the hepatic artery and portal vein (the two vessels supplying the liver) multiplied by the blood flow through those vessels. All values are approximations. Data compiled from Adkins et al, 1987; Adkins-Marshall et al, 1990; Myers et al, 1991a,b.
} 
enhanced the rate of NHGU $\sim 2.5$ - to threefold over that observed during peripheral glucose infusion (Adkins et al, 1987; AdkinsMarshall et al, 1990; Myers et al, 1991a, b). It was clear that the difference in NHGU was not due simply to differences in portal vein glucose levels, because at any portal glucose load examined, NHGU was twofold greater with portal delivery than with peripheral delivery (Myers et al, 1991b). NHGU was found to respond to small changes in the size of negative A-P gradient, an effect which plateaued at a gradient of approximately $-1 \mathrm{mM}$ (Pagliassotti et al, 1991).

Further work has been done to compare the time-course of the effect of the portal signal, insulin and the combination of insulin and the portal signal on NHGU (Pagliassotti et al, 1996). In dogs with fixed, basal levels of glucagon and insulin, hyperglycemia (arterial plasma glucose $\sim 13 \mathrm{mM}$, hepatic glucose load $283 \mu \mathrm{mol} . \mathrm{kg}^{-1} . \mathrm{min}^{-1}$ ) was maintained by peripheral glucose infusion for $90 \mathrm{~min}$. At that point, the dogs were maintained on a glucose infusion which kept the hepatic glucose load $\sim 283$ $\mu \mathrm{mol} . \mathrm{kg}^{-1}$. $\mathrm{min}^{-1}$ for an additional $240 \mathrm{~min}$. The animals were divided into four groups for this final 240 min period: one group continued to receive the peripheral glucose infusion with basal insulin (control group), one group received portal glucose with and basal insulin (portal group), one group received a peripheral glucose infusion with insulin at four-fold basal (insulin group) and one group received a portal glucose infusion with insulin at four-fold basal levels (insulin/portal group). The portal and insulin groups demonstrated similar maximal rates of $\mathrm{NHGU}\left(\sim 13\right.$ and $18 \mu \mathrm{mol} . \mathrm{kg}^{-1} \cdot \mathrm{min}^{-1}$, respectively). However, the maximal rate was achieved much more rapidly in the portal group than in the insulin group ( 15 vs $\sim 90 \mathrm{~min}$ ). The maximal rate of NHGU was highest in the insulin/portal group (23.6 $\left.\mu \mathrm{mol} . \mathrm{kg}^{-1} \cdot \mathrm{min}^{-1}\right)$, with this rate being achieved within 60 min (Pagliassotti et al, 1996).

\section{Neural signaling and NHGU}

Sympathetic and parasympathetic innervation of the liver exerts reciprocal control over hepatic glucose metabolism and glycogen synthesis. Stimulation of the sympathetic innervation, either at the level of the ventromedial hypothalamus (VMH), the subdiaphragmatic splanchnic nerve or the hilus of the liver, increases hepatic glucose and lactate production and raises the blood glucose level (Lautt, 1983; Shimazu, 1987; Nijima, 1989). VMH stimulation increases the activity of phosphorylase without changing glycogen synthase, and thus reduces the liver glycogen content (Lautt, 1983; Shimazu, 1987; Niijima, 1989). On the other hand, parasympathetic stimulation at the level of the lateral hypothalamus or the cervical vagus nerve increases hepatic glycogen synthesis and reduces hepatic glucose output (Lautt, 1983; Shimazu, 1987; Niijima, 1989). LH stimulation is associated with enhanced activity of glycogen synthase, without a change in phosphorylase activity (Lautt, 1983; Shimazu, 1987; Niijima, 1989). Moreover, the firing rate in the afferent fibers of the hepatic branch of the vagus nerve is inversely proportional to the portal vein glucose concentration (Niijima, 1989).

Several in vivo studies support a role for the nervous system in regulation of NHGU in response to a glucose load. Atropine infusion to block the parasympathetic nervous system reduced NHGU in response to an enteral glucose load by $44 \%$ in conscious dogs (Chap et al, 1985). In dogs which had undergone complete surgical denervation of the liver, the response to the portal signal was significantly blunted (Adkins-Marshall et al, 1992), but the rate of NHGU in response to a peripheral glucose infusion was significantly enhanced, compared to 
that seen in normally innervated dogs (Adkins-Marshall et al, 1992; Moore et al, 1996). Rates of NHGU during peripheral and portal glucose infusion were similar in the hepatic-denervated dogs, and these rates were intermediate between the rates observed during peripheral and portal glucose infusion in the hepatic-innervated dogs (Adkins-Marshall et al, 1992). These data are consistent with the existence of a tonic inhibition of NHGU in the postabsorptive state. This inhibition may be produced by sympathetic neural tone, as well as by the hormonal milieu (low levels of circulating insulin and a lower insulin:glucagon ratio than that which prevails following glucose feeding). In response to enteral or portal glucose delivery, the parasympathetic nervous system is activated. The parasympathetic nervous system can enhance NHGU both directly, by stimulating hepatic glucose uptake and glycogen synthesis, and indirectly through stimulation of insulin release (Lautt, 1983; Shimazu, 1987; Niijima, 1989). $\mathrm{NHGU}$ in response to peripheral and portal glucose delivery is similar in hepatic-denervated animals because there is no neurally-mediated inhibition during peripheral delivery and no enhancement during portal delivery.

\section{HEPATIC GLYCOGEN SYNTHESIS}

Evidence suggests that the portal signal is not only a determinant of NHGU but also participates in the regulation of hepatic glycogen synthesis. Hepatic glycogen synthase activity and net hepatic glycogen synthesis were compared at two time points (30 and $240 \mathrm{~min}$ ) in dogs who received peripheral glucose infusion in the presence of basal insulin levels (control group), peripheral glucose infusion with four-fold basal insulin (insulin group), portal glucose infusion with basal insulin (portal group) or portal glucose infusion with four-fold basal insulin (insulin/portal group) (Pagliassotti et al, 1996). In the portal group, glycogen synthase activity and net hepatic glycogen synthesis were significantly increased at $30 \mathrm{~min}$ over that in the control group, and net hepatic glycogen synthesis was significantly greater than in the insulin group (Pagliassotti et al, 1996). At $240 \mathrm{~min}$, hepatic glycogen synthase activity in the insulin group was significantly greater than that in the control and portal groups, and net hepatic glycogen synthesis was significantly greater in both the insulin and portal group dogs than in the control animals. Net hepatic glycogen synthesis in the insulin/portal dogs was significantly higher than in the portal and control group dogs $(134 \pm 17 \mu \mathrm{mol} / \mathrm{g}$ in insulin/portal vs $65 \pm 16$ in portal and $84 \pm 17$ in insulin) (Pagliassotti et al, 1996). Thus, the portal signal serves not only to enhance the uptake of glucose by the liver but also to direct a significant portion ( $75 \%$ ) of the glucose into glycogen. The results suggest that insulin and the portal signal act in cooperation with the portal signal stimulating early glycogen accumulation. The effect of the portal signal on glycogen synthase appears to ebb over time, and hyperinsulinemia then assumes a primary role in stimulating glycogen synthase and glycogen accumulation (Pagliassotti et al, 1996).

\section{EFFECTS OF THE PORTAL SIGNAL ON NONHEPATIC TISSUES}

The portal signal affects tissues other than the liver. Both pancreatic insulin output and circulating insulin levels were significantly greater during intraportal glucose infusion than during peripheral glucose infusion, although the glucose infusion rate and the steady-state arterial plasma glucose levels were the same with each delivery route (Dunning et al, 1995). Autonomic blockade with hexamethonium prevented the enhancement of insulin levels with portal 
glucose delivery (Dunning et al, 1995). In addition, the increase in NHGU during intraportal glucose delivery is associated with a decrease in disposition of glucose by nonsplanchnic tissues (Adkins et al, 1987). These peripheral effects may be neurallymediated; changes in hypothalamic activity are accompanied by changes in glucose uptake in skeletal and cardiac muscle (Takahashi et al, 1992; Lang et al, 1995). Moreover, hepatic receptors appear to be key elements contributing to the sensations of hunger and satiety. Both the frequency and size of meals are altered in rats in which neural signaling between the liver and central nervous system is interrupted by total hepatic denervation or hepatic vagotomy (Ratto et al, 1991; Yang et al, 1992). Thus, the portal signal is not an isolated mechanism for regulating hepatic carbohydrate but instead appears to be part of an elaborate system for control of whole body carbohydrate metabolism.

\section{REFERENCES}

Abumrad NN, Cherrington AD, Williams PE, Lacy WW, Rabin D (1982) Absorption and disposition of a glucose load in the conscious dog. Am J Physiol 242, E398-E406

Adkins BA, Myers SR, Hendrick GK, Stevenson RW, Williams PE, Cherrington AD (1987) Importance of the route of intravenous glucose delivery to hepatic glucose balance in the conscious dog. $J$ Clin invest 79, 557-565

Adkins-Marshall BA, Myers SR, Hendrick GK, Williams PE, Triebwasser K, Floyd B, Cherrington AD (1990) Interaction between insulin and glucose-delivery route in regulation of net hepatic glucose uptake in conscious dogs. Diabetes 39, 87-95

Adkins-Marshall B, Pagliassotti MJ, Asher JR, Connolly CC, Neal DW, Wilfiams PE, Myers SR, Hendrick GK, Adkins RB Jr, Cherrington AD (1992) Role of hepatic nerves in response of liver to intraportal glucose delivery in dogs. Am J Physiol 262, E679-E686

Barrett EG, Ferrannini E, Gusberg R, Bevilacqua S, DeFronzo RA (1985) Hepatic and extrahepatic splanchnic glucose metabolism in the postabsorptive and glucose fed dog. Metabolism 34, 410-420
Bergman RN, Blier JR, Hourigan PM (1982) Intraportal glucose infusion matched to oral glucose absorption: lack of evidence for "gut factor" involvement in hepatic glucose storage. Am J Physiol 227, 1314 1322

Chap Z, Ishida T, Chou J, Lewis R, Hartley C, Entman M, Field JB (1985) Effects of atropine and gastric inhibitory polypeptide on hepatic glucose uptake and insulin extraction in conscious dogs. $J$ Clin Invest 76, 1174-1181

DeFronzo RA, Ferrannini E (1987) Regulation of hepatic glucose metabolism in humans. Diab Metab Rev 3 , 415-459

DeFronzo RA, Ferrannini E, Hendler R, Wahren J, Felig $P(1978)$ Influence of hyper-insulinemia, hyperglycemia, and the route of glucose administration on splanchnic glucose exchange. Proc Natl Acad Sci USA 75, 5173-5177

Dunning B, Neal D, Scott M, Cherrington A (1995) Neurally-mediated augmentation of the pancreatic response to glucose with portal glucose delivery in conscious dogs. Diabetes $44,191 \mathrm{~A}$

Ishida T, Chap Z, Chou J, Lewis R, Hartley C, Entman M, Field JB (1983) Differential effects of oral, peripheral intravenous, and intraportal glucose on hepatic glucose uptake and insulin and glucagon extraction in conscious dogs. J Clin Invest 72, 590-601

Lang $\mathrm{CH}$, Ajmal M, Baillie AGS (1995) Neural control of glucose uptake by skeletal muscle after central administration of NMDA. Am J Physiol 268, R492R497

Lautt WW (1983) Afferent and efferent neural roles in liver function. Prog Neurobio/ 21, 323-348

Liljenquist JE, Mueller GL, Cherrington AD, Keller U, Chiasson JL, Perry JM, Lacy WW, Rabinowitz D (1977) Evidence for an important role for glucagon in the regulation of hepatic glucose production in normal man. J Clin Invest 59, 369-372

Liljenquist JE, Bloomgarden ZT, Cherrington AD, Perry JM, Rabin D (1979) Possible mechanism by which somatostatin-induced glucagon suppression improves glucose tolerance during insulinopenia. Diabetologia 17, 139-143

McGuinness OP, Myers SR, Neal D, Cherrington AD (1989) Chronic hyperinsulinemia decreases insulin action but not insulin sensitivity. Metabolism 39, 931937

Moore MC, Cherrington AD, Cline G, Pagliassotti MJ Jones EM, Neal DW, Badet C, Shulman GI (1991) Sources of carbon for hepatic glycogen synthesis in the conscious dog. J Clin Invest 88, 578-587

Moore MC, Rossetti L, Pagliassotti MJ, Monahan M, Venable C, Neal D, Cherrington AD (1996) Neural and pancreatic influences on net hepatic glucose uptake and glycogen synthesis. Am J Physiol (Endocrinol Metab) (in press) 
Myers SR, McGuinness OP, Neal DW, Cherrington AD (1991a) Intraportal glucose delivery alters the relationship between net hepatic glucose uptake and the insulin concentration. J Clin Invest 87, 930-939

Myers SR, Biggers DW, Neal DW, Cherrington AD (1991b) Intraportal glucose delivery enhances the effects of hepatic glucose load on net hepatic glucose uptake in vivo. $J$ Clin Invest 88, 158-167

Niijima A (1989) Nervous regulation of metabolism. Prog Neurobio/ 33, 135-147

Pagliassotti MJ, Myers SR, Moore MC, Neal DW, Cherrington AD (1991) Magnitude of negative arterialportal glucose gradient alters net hepatic glucose balance in conscious dogs. Diabetes 40, 1659-1668

Pagliassotti MJ, Holste LC, Moore MC, Neal DW, Cherrington $A D$ (1996) Comparison of the time courses of insulin and the portal signal on hepatic glucose and glycogen metabolism in the conscious dog. $J$ Clin Invest 97, 81-91

Radziuk J (1987) Tracer methods and the metabolic disposal of a carbohydrate load in man. Diab Metab $\operatorname{Rev} 3,231-267$
Ratto C, Gleason JR, Yang ZJ, Bellantone R, Crucitt $F$, Meguid MM (1991) Change in meal size, number and duration after neural isolation of liver and with TPN. Physiol Behav 50, 607-612

Sacca L, Cicala M, Trimarco B, Ungaro B, Vigorito C (1982) Differential effects of insulin on splanchnic and peripheral glucose disposal after an intravenous glucose load in man. $J$ Clin Invest 70, 117-126

Shimazu T (1987) Neuronal regulation of hepatic metabolism in mammals. Diab Metab Rev 3, 185 206

Shulman GE, Liljenquist JE, Williams PE, Lacy WW, Cherrington AD (1978) Glucose disposal during insulinopenia in somatostatin-treated dogs. The roles of glucose and gilucagon. J Clin Invest 62, 487-491

Takahashi A, Sudo M, Minokoshi Y, Shimazu T (1992) Effects of ventromedial hypothalamic stimulation on glucose transport system in rat tissues. Am J Physiol 263, R1228-R1234

Yang ZJ, Ratto C, Gleason JR, Bellantone R, Crucitti $F$, Meguid MM (1992) Influence of anterior subiaphragmatic vagotomy and TPN on rat feeding behavior. Physiol Behav 51, 919-926 